\title{
A potential explanation of the reported low prevalence of hepatitis $B$ virus infection in patients with systemic lupus erythematosus
}

\author{
William H. James
}

Received: 17 November 2010 / Accepted: 17 February 2011 / Published online: 10 March 2011

(C) Springer-Verlag 2011

Zhao et al. [1] reported a low prevalence of hepatitis B virus (HBV) infection in patients with systemic lupus erythematosus (SLE). These authors were unable to explain their finding, so I should like to offer one.

There have been two large prospective studies of HBV and hepatocellular cancer (HCC) [2, 3]. Incidental findings in each were that healthy volunteer HBV carriers had higher testosterone $(\mathrm{T})$ concentrations than healthy uninfected volunteer controls $(P=0.045$ and $P=0.0006$, respectively, both two-way). The reason for this is not established and not directly relevant to the present note (though it may relate to variation in rates of viral replication in different hormonal environments, if we may be guided by mouse models [4-6]).

It has been recognised for many years that androgen deficiency can predispose to and accelerate murine lupus [7]. There is also some evidence that androgen deficiency may be associated with the development of SLE in humans $[8,9]$. Accordingly, I suggest that the finding of Zhao et al. [1] may be explained by the low androgen levels of patients with SLE.

\section{References}

1. Zhao J, Qiu M, Li M, Lu C, Gu J (2010) Low prevalence of hepatitis $\mathrm{B}$ in patients with systemic lupus erythematosus in southern China. Rheumatol Int 30:1565-1570
2. Yu MW, Chen C-J (1993) Elevated serum testosterone levels and risk of hepatocellular cancer. Cancer Res 53:790-794

3. Yuan JM, Ross RK, Stanczyk FZ, Govindarajan S, Gao YT, Henderson BE, Yu MC (1995) A cohort study of serum testosterone and hepatocellular carcinoma in Shanghai, China. Int J Cancer 63:491-493

4. Wang SH, Yeh SH, Lin WH, Wang HY, Chen DS, Chen PJ (2009) Identification of androgen response elements in the enhancer I of hepatitis B virus: a mechanism for sex disparity in chronic hepatitis B. Hepatology 50:1392-1402

5. Wu MH, Ma WL, Hsu CL, Chen YL, Ou JHJ, Ryan CK, Hung YC, Yeh S, Chang C (2010) Androgen receptor promotes hepatitis B virus-induced hepatocarcinogenesis though modulation of hepatitis B RNA transcription. Sci Transl Med 2(32):32ra35

6. Yeh SH, Chen PJ (2010) Gender disparity of hepatocellular cancer: the roles of sex hormones. Oncology 78(Suppl 1):172-179

7. Gordon C, Wallace DJ, Shinada S, Kalunian KC, Forbess L, Braunstein GD, Weisman MH (2008) Testosterone patches in the management of patients with mild/moderate systemic lupus erythematosus. Rheumatology 47:334-338

8. Lahita RG, Bradlow HL, Ginzler E, Pang S, New M (1987) Low plasma androgens in women with systemic lupus erythematosus. Arth Rheum 30:241-248

9. Straub RH, Weidler C, Demmel B, Herrmann M, Kees F, Schmidt M, Scholmerich J, Schedel J (2004) Renal clearance and daily excretion of cortisol and adrenal androgens in patients with rheumatoid arthritis and systemic lupus erythematosus. Ann Rheum Dis 63:961-968

W. H. James $(\varangle)$

The Galton Laboratory,

University College London, Wolfson House, London, UK

e-mail:whjames@waitrose.com 